\title{
PRE-ESTABLISHED HARMONY: Studi Pemikiran Leibniz Dalam Perspektif al Quran
}

\author{
Moh. Padil
}

Fakultas Tarbiyah PAI Universitas Islam Negeri Maulana Malik Ibrahim Malang, Jalan gajayana No.50 Malang. 081555766925 e-mail: Mbah_padil@yahoo.com

\section{Abstract}

Gorfried Wilhem Leibniz (1646.1716) is someone who concentrated his thought on the logical and metaphysical concept. Metaphysical concept believes that the concept of truth on the life of the nature is dominated by the definite balance. It is very interesting when Leibniz's physical concept is discussed based on the Qur'anic teaching. According to the Qur'anic teaching, the God is al-Khaliq, the creator of the universe and human. And the God descends His prophet to inform, to explain, to interpret and to give the directions to implement the Qur'an in the human's life. As long as human's lives in the world follow the God's way will reach the save ness and happiness. While according to Leibniz, the society who can not adopt to the cosmos' rule will be destroyed. According to Qur'an, someone who does not follow the God's will be destroyed, because the God's firman is the guidance for human for reaching taqwa and merciful.

Key words: metaphysical, Qur'anic teaching

Ulul Albab, Vol. 10, No. 1, 2009 


\section{Pendahuluan}

Kodrati manusia sebagai makhluk sosial mendasarkan pola pikir dan tata bertindak pada suatu pola budaya tertentu dan struktur tertentu yang memberi makna, arah dan bentuk kegiatannya. Wadah yang disebut masyarakat yang terdiri dari struktur satuan-satuan agregatif, kemudian memunculkan watak masyarakat dalam bentuk organisasi untuk merealisasikan hidup yang teratur. Suatu interaksi antar individu dalam bentuk kerjasama dalam membagi tugas atau untuk mengokohkan eksistensi individu dalam pekerjaannya masing-masing menjadi penting.

Manusia yang hidup di tengah-tengah alam kodrati membentuk kehidupan bermasyarakat bukanlah merupakan monopolinya, hewan juga sebagai makhluk kodarati yang dapat membentuk kehidupan bermasyarakat, seperti; semut, serangga, gajah, harimau, burung dan sebagainya. Seluruh tertib dan keteraturan dunia, termasuk keteraturan masyarakat berasal dari suatu tertib dan keteraturan dunia, termasuk keteraturan masyarakat berasal dari suatu tertib dan keteraturan yang adi manusiawi, abadi, tidak berubah dan ahistoris. Menurut Aristoteles susunan masyarakat memantulkan atau mencerminkan susunan kosmos yang abadi.

Gotfried Wilhelm Leibuiz (1646-1716) adalah seseorang yang dianggap representatif mewakili garis pemikiran Aristotelian yang.mendasarkan nalar pada alur logikal dan metafisikal. Alur metafisikal meyakini konsep kebenaran bahwa kehidupan alam semesta ini telah dikuasai sejak awal oleh suatu keselarasan yang terwujud secara pasti.

Menurut ajaran al Quran, Tuhan itu al Khalik, Maha Pencipta alam dan manusia. Kepada manusia diturunkan RasulNya untuk memberitakan, menjelaskan, memerinci, menafsirkan dan memberikan teladan bagaimana mewujudkan wahyu dalam kehidupan manusia dialam raya (Gazalba, 1976: 226). Kehidupan alam dan manusia selama mengikuti jalan petunjuknya akan mencapai tingkat salam, yang diartikan keselamatan dan kesenangan.

Menjadi sangat menarik ketika konsep alur fisikal Leibniz dikaji menurut persepsi al Quran. Menurut Aristoteles masyarakat yang tidak 
dapat menyesuaikan diri dengan susunan kosmos yang abadi, berarti ia menghancurkan diri. Menurut al Quran manusia yang tidak mengikuti petunjuk Tuhan, akan celaka hidupnya, karena sabda-sabda Tuhan (al Quran) merupakan petunjuk manusia agar mencapai prestasi taqwa dan mendapat keberuntungan hidup (QS. al Baqarah: 1-5).

\section{Bangunan Filsafat Leibniz}

Latar belakang pendidikan Leibniz adalah di bidang hukum, ia memperoleh gelar doktor pada tahun 1666 di Atdarf. Ketika di Jerman ia belajar filsafat neo-skolastik Aristotelian yang dipertahankan sepanjang hidup. Kemudian ia pindah ke Paris dan mulai belajar filsafat Cartesionisme dan materialisme Gassendi yang mulai berpengaruh dalam filsafatnya.Di Paris ia juga mulai mengenal filsafat Malebranche dan Arnauld Si Jansenis. Dan terakhir ia bergabung untuk mencela Spinoza.

Filsafat populer Leibniz bisa ditemukan dalam Monadology dan Principles of Nature and of Greece. Dasar dari optimisme teologinya ada dalam Theodice (Russel, 2002: 764). Leibniz mendasarkan filsafatnya pada konsep tentang substansi, seperti Descartes dan Spinoza, tetapi berbeda dengan keduanya dalam hal hubungan antara jiwa dan materi serta jumlah sustansi. Menurut Descartes ada tiga substansi, yaitu tuhan, jiwa dan materi, spinoza hanya mengakui substansi Tuhan saja. Bagi Descartes esensi dari materi adalah berkembang bagi spinoza, pengembangan dan jiwa hanya milik Tuhan.

Leibniz berpendapat bahwa pengembangan tidak dapat diatribusikan pada sebuah substansi. Alasannya adalah bahwa pengembangan melibatkan pluralitas, oleh karenanya hanya bisa terjadi pada kumpulan substansi (Russel, 2002: 765). Setiap tunggal pasti tidak bisa berkembang. Dengan demikian Leibniz percaya kepada ketidakterhinggaan materi yang disebut dengan monade-monade. Setiap monade akan memilki beberapa sifat fisik, tetapi ketika dianggap abstrak, senyatanya setiap monade adalah jiwa. Leibniz akhirnya punya kesimpulan bahwa materi dan kuantitas sama saja, ia menempatkan materi dan roh pada taraf yang sama (Peursen, 1991:

Ulul Albab, Vol. 10, No. 1, 2009 
147) la mengambarkan kenyataan yang dipandang dari dalam terdiri dari unsur-unsur daya rohani yang disebut dengan monade, kalu unsur-unsur itu didekati dari luar maka nampaknya seperti materi dan kekuasaan. Konsep tentang kuantitas makin menghampakan konsep materi, bahkan pengertian tentang ruang bukan kosong lagi, melainkan dipersempit, disamakan dengan angka dan ukuran.

Ketidakterhinggaan Leibniz yang disebut dengan monade-monade dapat dibuktikan dengan adanya banyak tingkat benda yang terpisah, tidak dapat direduksi 'dan bersifat independen di alam semesta. Fakta plural berasal dari adanya dua realitas tak tertolak, yaitu antara Tuhan dan makhluk (al Faruqi, 1982: 11). Dalam diri makhluk terdapat tatanan ruiang dan waktu, pengalaman, penciptaan, kekayaan dan sejarah, kebudayaan dan pengetahuan, peradaban, dunia benda, tanaman dan hewan, manusia, jin, malaikat, langit dan bumi, surga dan neraka, dan semua salinan serta turunan yang bermakna keragaman atas semua realitas. Menurut al Faruqi semua itu bersumber kepada yang satu yaitu Allah.

Menurut Leibniz substansi-substansi berdasarkan hakikatnya sendiri lingkup secara sempurna. Dunia terdiri dari substansi-substansi yang tak terhitung jumlahnya itu disebut momad-momad yang masing-masing bebas dari semua yang lain. Tuhan merupakan Supermomad, pencipta semua momad (Solomon, 1996: 370). Setiap momad mencerminkan sosok diri yang kecil atau jiwa yang tidak tercendela. Pencenapan sebuah monade bukan pencenapan dalam pengertian yang lazim, yang lebih tepat hanya merupakan keadaan-keadaan internal yang bersesuaian dengan keadaankeadaan internal semua monad lainnya dalam suatu harmoni yang sudah ditetapkan sebelumnya. Laibniz dalam membangun filsafatnya diatas dasar logika dan metafisika. Logika Leibniz mengarah pada logika universal yang di dalamnya dapat memecahkan semua masalah dengan perhitungan tanpa pertumpahan darah dan rasional (Solomon, 1996: 379). Tidak adanya sesuatu yang terjadi tanpa adanya suatu alasan, karena semua alasan adalah alasan-alasan Tuhan dan Tuhan menentukan alam semesta, sehingga kita merasa yakin bahwa alsan-alasan ini adalah alasan-alasan yang baik. Tuhan

Ulul Albab, Vol. 10, No. 1, 2009 
hanya akan memilih yang terbaik dari sumua dunia yang mungkin diantara pilihan yang tak terhingga jumlahnya diantara dinia-dunia yang mungkin berbeda-beda.

Menurut Solomon logika Leibniz bisa saja diperdebatkan, tetapi visi Leibniz tidak bisa disangakal yang bersifat memperbaiki akhlak. Pada masamasa kekacauan kata Solomon, visi itu senantiasa menjadi suatu hal yang melegakan, karena ada alasan tertentu dibalik suatu peristiwa. Apa yang kita lihat suatu keburukan hanyalah karena visi kita yang terbatas (Solomon, 1996: 379).

Pandangan metafisika Leibniz menekankan kepada monad-monad sebagai entitas spiritual tidak berlokasi dalam ruang dan waktu, bersifat batiniyah dan bukan lahiriyah (Solomon, 1996: 381). Bagi Leibniz ruang dan waktu bersifat relatif, baik terhadap benda-benda dan peristiwa-peristiwa yang terjadi secara berurutan. Menurutnya ruang adalah koeksistensi dan waktu adalah tatanan rangkaian.

Leibniz dengan teori monadenya dan Tuhan sebagai Supermonad berarti monad-monad yang tak terhingga jumlahnya berasal dari Supermonad. Filosof muslim al-Kindi yang terkenal sebagai filosof Arab pertama berusaha memadukan unsur-unsur filosof Aristoteles dan Plato. Dari sudut ini akan bertemu dengan Leibniz dalam teori emanasi yaitu sesuatu yang ada mengalir dari yang ada paling tingggi (Peursen, 1991: 134).

\section{Konsep Leibniz Tentang Pre-Established Harmony}

Pre.Established Harmony adalah sebuah konsep yang meyakini bahwa kehidupan alam semesta alam ini adalah suatu tertib keselarasan yang telah terwujud secara pasti sejak awal mulanya (Soetandyo, 2002: 2). Menurut Scott Gardon, Leibniz tidak begitu saja menyatakanbahwa dunia adalah tatanan yang harmonis. Leibniz berusaha menyimpulkan yang disertai dengan dua aksioma utama, pertama, keberadaan Tuhan adalah wujud yang sempurna dan yang menciptakan dunia. Kedua, Leibniz memakai prinsip-prinsip alasanalasan yang cukup, bahwa tidak satupun yang ada dan terjadi tanpa adanya alasan. Dan tidak ada satupun yang gagal untuk ada, dan gagal untuk terjadi

Ulul Albab, Vol. 10, No. 1, 2009 
tanpa adanya alasan. Ciri khas dunia adalah pada tiadanya jalan aksidental, bagi Tuhan sendiri tidak bertindak secara tidak terduga.Dunia tidak bisa menjadi sesuatu yang berbeda dengan apa yang ada, berdasarkan aksioma diatas, kemungkinan bentuk-bentukeksistensi sesuatu yang sebenarnya ada adalah sesuatu yang secara logis bertentangan (Gordon, 1991: 214).

Scott Gordon mencontohkan keselarasan suatu orkestra sebagai suatu Pre-Established Harmony, orkestra yang digambarkan Gordon adalah terdiri dari sekian banyak pemain yang telah memainkan bagian masing-masing yang sekaligus secara mandiri, tetapi secara keseluruhan (total) menjadi sebuah keselarasan. Hal ini dapat di pahamkan bahwa keselarasan itu terwujud tidak karena adanya proses sebab akibat. Pemain yang satu bertugas untuk memainkan alat musik bukan sebagai penyebab bermainnya pemain musik yang lain untuk memainkan alat musik. Keselarasan terwujud karena adanya partitur yang telah ada dan tercipta serta ditetapkan sejak awal mulanya. Partitur itu telah lahir sebagai bagian yang inheren didalam setiap satuan yang ada dalam totalitas sistem (Gordon, 1991: 214-215).

Leibniz sendiri menggambarkan sebuah Pre-Established Harmonydengan perubahan-perubahan sebuah monade dan perubahan-perubahan di monade yang lain, yang menghasilkan kemiripan interaksi. Ini jelas merupakan pengembangan dari dua jam yang berdetak pada saat yang sama, karena masing-masing mempunyai waktu yang sempurna. Leibniz memiliki jam yang tak terbatas jumlahnya. Semua diatur oleh sang pencipta untuk berdering pada saat yang sama, bukan karena jam-jam itu saling mempengaruhi, karena masing-masing adalah sebuah mekanisme yang sepenuhnya akurat. Kepada mereka yang menganggap harmoni, deterministik itu janggal. Leibniz menunjukkan bukti yang mengagumkan dari apa yang dihasilkan oleh eksistensi Tuhan (Russel, 2002: 767).

Ada empat argumentasi Leibniz yang dipergunakan untuk memperkuatkan eksistensi Tuhan, pertama argumentasi ontologis, kedua, argumentasi kosmologis, ketiga, argumentasi dari kebenaran-kebenaran abadi dan keempat, argumentasi dari harmoni yang telah ditetapkan (Russel, 2002: 768). Dari keempat argumentasi tersebut, Leibniz menguatkan dari 
argumentasi keempatnya.

Menurut Leibniz, argumentasi harmoni yang telah ditetapkan sebelumnya, hanya shoheh bagi mereka yang menerima unsur-unsur tak bercendela yang seluruhnya mencerminkan alam semesta. Argumentasi itu berbunyi bahwa, jika semua jam saling menjaga waktu masing-masing tanpa interaksi kausal apapun, pastilah ada penyebab tunggal dari luar yang mengatur semua jam.

Leibniz menjelaskan tentang Pre-Established Harmony dengan monademonade yang membentuk sebuah herarki, dimana sebagian lebih tinggi dari pada yang lain. Dalam semua monade terdapat suatu tingkat kebingungan dalam mempersepsi, tetapi tingkat kebingungannya berbeda-beda sesuai dengan kedudukannya masing-masing dalm herarki. Tubuh manusia seluruhnya tersusun atas monade-monade, masing-masing adalah sebauah jiwa yang abadi, tetapi ada sebuah monade dominan yang disebut jiwa manusia sebagai penyusun tubuh manusia. Perubahan dalam tubuh manusia terjadi demi kepentingan monade dominan tersebut.

Prinsip-prinsip Tuhan menciptakan dunia menurut Leibniz menggunakan prinsip-prinsip alasan yang memadahi, tetapi tidak bertindak sebagai pengatur atas apa yang diciptakannya secara terus menerus (Gordon, 1991: 214). Penafsiran Tuhan menciptakan dunia melalui tatanan yang harmonis, karena Tuhan merancang dunia terdiri dari monade yang dapat di susun. Monade digambarkan oleh Leibniz sebagai entitas yang secara total independen satu sama lain. Antara monade satu dengan monade yang lain tidak saling berinteraksi.

Penafsiran Tuhan tidak bertindak sebagai pengatur atas apa yang telah diciptakan secara terus menerus adalah Tuhan tidak mengatur secara langsung, tetapi melalui hukum alam (Gordon, 1991: 214) dalam satu tatanan kausal. Denis Leibniz ingin mengatakan bahwa konsep harmoni dikejawantahkan dalam ciptaan dunia menurut tata tertib yang telah dirancang oleh Tuhan. Keberadaan dunia menjadi diterministik, karena segala sesuatu yang terjadi telah tertulis dalam program Tuhan. Ia sangat

Ulul Albab, Vol. 10, No. 1, 2009 
hati-hati menerima deterministik, karena dipihak lain manusia mempunyai kebebasan yang bertanggung jawab secara individual. Dipihak lain, dunia tidak deterministik karena segala sesuatu diarahkan oleh hukum alam dalam satu tatanan kausal. Disini kebiungunan banyak orang tentang konsep Leibniz, karena disatu pihak, ia memerima deterministik secara hati-hati, dipihak lain, ia menerima tidak deterministik dan yang terakhir ini sebagai konsep filsafatnya. Leibniz sangat kuat tentang ketidakdeterministikan ketika menata monade-monade, tetapi ketika berhadapan dengan perbuatan manusia, ia sulit untuk menolak ketidakmampuanmanusia dalam hal-hal tertentu. Sebenarnya Leibniz mengakui kelemahan-kelemahan manusia dan sifat manusia dalam menghadapi kelemahan tersebut dengan mencari perlindungan kepada Tuhan.

Konsep Pre-Established leibniz merujuk kepada hakekat kejadiankejadian duniawi yang harmonis inheren dalam keadaan jasmani sesuatu. Dunia bukanlah terjadi setelah semua tatanan kausal berkaitan dengan konsep umum tentang sebab yang menuntut monade dapat saling mempengaruhi satu sama lain. Laibniz berpendapat konsepsi com mousence tentang kausalitas semata-mata ilusi, berhubungan dengan kegagalan untuk mengapresiasi bahwa segala sesuatu itu ada sebagaimana adanya, dan tejadi karena Tuhan telah menyusunnya sebelum kejadian itu berlangsung. Leibnis membangun suatu sistem yang sepenuhnya berbeda. Menurutnya, dunia tidak deterministik jika diarahkan kepada hukum alam dalam suatu tatanan kausal. Dunia menjadi deterministik jika diarahkan kepada sesuatu yang terjadi telah tertulis dalam lembaran Tuhan (Gordon, 1991: 214).

Scott Gordon selanjutnya menjelaskan bahwa dunia adalah satu continous plenitude eksistensi dalam pengertian bahwa keseluruhan alam ini di penuhi dengan wujud. Setiap yang wujud bwebeda dari hal-hal yang berdekatan dengannya, tetapi hanya sampai satu tingkat yang sangat kecil, sehingga keseluruhan ini membentuk satu rantai wujud agung yang berkelanjutan. Diktum para ahli fisika bahwa alam membenci kekosongan tidak banyak bermakna. Sedangkan diktum natura nan facit saltum (alam tidak menciptakan langkah), dapat dipergunakan sebagai satu jalan yang

Ulul Albab, Vol. 10, No. 1, 2009 
menarik untuk mengungkap kontinuitas perubahan temporal, seperti proses perubahan organik. Metafisika abad 17 berpandangan dunia yang statis adalah contineum dari hal-hal yang berbeda secara tipis, mungkin juga akan terjadi kekosongan di alam kosmos, seperti kekosongan ruang yang sangat luas diantara bintang-bintang dan mungkin juga nampak menjadi ciri lain. Perbedaan antara entitas ciptaan Tuhan, seperti pohon dan batu. Hal ini lebih kepada penampaan berhubungan dengan ketidakmampuan kita untuk melihat seluruh yang wujud (Gordon, 1991: 215).

Leibniz mengakui bahwa Tuhan itu sebagai illat (sebab) yang pertama bagi wujudnya segala sesuatu yang ada. Setiap yang terbatas dan berkesudahan dan dapat diketahui oleh pandangan inderawi termasuk bagian mumkinan (boleh ada dan boleh tidak ada), yang tidak mengandung sesuatu yang mewajibkan ada dengan dzatnya sendiri. Sebab yang pertama bagi wujudnya alam ini, merupakan sebab yang pertama bersifat kekal, sedangkan keberadaan alam adalah sesuatu yang mungkin ada. Menurut Leibniz alam semesta adalah yang paling baik dari beberapa kemungkinan yang ada.

\section{Konsep Pre-Established Harmony Menurut al Quran}

Menurut Islam konsep Pre-Established Harmony dapat dipandang dari uraian tentang eksistensi Tuhan, penciptaan alam dan hukum alam. Ketiganya sebelum terjadi sesuatu merupakan monade tunggal yang disebut dzat Tuhan. Sepanjang pemikiran filosofis dan analisis ilmiah, tidak pernah menyentuh wilayah ini. Sesungguhnya dzat Tuhan tidak dapat dicapai oleh semua penglihatan sedang ia dapat mencapai penglihatan-penglihatan itu. Ia Maha Halus serta Maha Waspada (QS. al An'am: 103). Islam memakai konsep al Khaliq (Tuhan Maha Pencipta) dan al Makhluk (sesuatu yang tercipta) setelah Tuhan sendiri mengejawantah. Konsep al Khaliq adalah Tuhan tidak mempunyai batas, Tuhan adalah ghoib, Tuhan adalah sempurna. Oleh karena itu Tuhan tidak dapat dilihat secara inderawi.

Tetapi Tuhan ada, bagaimana cara mengetahui Tuhan? secara langsung tidak akan pernah terjawab, jika di upayakan, ada jalan secara tidak langsung. Misalnya melalui wahyu, Tuhan mengirim utusan (Rasul) yang membawa 
pesan dari Tuhan untuk disampaikan kepada seluruh umat manusia. Pesan Tuhan itu ditulis dalam al Kitab. Juga dapat melalui hikmat (filsafat), Tuhan mengenugerahkan kebijaksanaan dan kecerdasan berpikir kepada manusia untuk mengenal adanya Tuhan dengan memperhatikan alam semesta sebagai bukti hasil ciptaannya. Hasil ciptaan Tuhan serba teratur, cermat dan hatihati. Jalan lainnya adalah fitrah yang diakui oleh manusia yang sejak lahir telah membawa identitas Tuhan yang dibuktikan dengan pengakuan, bahwa manusia mempunyai keterbatasan dan keterbatasan ada yang mencipta. Ketika keterbatasan muncul, sifat ketuhanan yang ada dalam diri manusia muncul yang diimplementasikan dalam bentuk mencari perlindungan (Ahnan, tt: 196).

Hasil yang diperoleh manusia dalam usahanya perkenalan dengan Tuhan adalah hanya melalui eksistensiNya. Tuhan memperkenalkan dirinya melalui ciptaanNya. Alam semesta sebagai eksistensi Tuhan dalam kehidupan meliputi langit, bumi, gunung, samudra dan sebagainya. Langit adalah alam semesta, bumi adalah alam semesta dan seterusnya diciptakan melalui proses hukum penciptaan yang fondamental, yaitu proses yang mensyaratkan adanya pencipta, bahan, tujuan, ukuran, waktu serta di dalamnya ada mekanisme hukum yang bekerja secara otomatis dan serta internal mengatur kehidupannya (Asy'ari, 2002: 192).

Alam semesta sebagai eksistensi Tuhan tidak terbatas. Yang terbatas adalah wujud-wujud keseluruhan sejenis dari bagian alam, seperti langit, bumi, gunung, samudra dan manusia. Wujud-wujud keseluruhan sejenis ini akan rusak, bersifat sementara, berubah dan bahkan akan mati. Alam semesta hanya dapat dipahami melalui kemampuan intelektual dalam dimensi spiritualnya, yakni dapat memahami tanda-tanda Tuhan atau ayat-ayat Tuhan yang terkandung dan tersembunyi dalam semua wujud keseluruhan sejenis.

Eksistensi Tuhan berada dalam tingkatan-tingkatan wujud yang bersifat struktural dan herarkis. 
Tuhan

2

Eksistensi Tuhan, Pencipta Pertama: Alam Semesta 3

Alam Besar : Kumpulan Jenis: Air, Udara, Bumi Langit, Manusia

4

Alam Kecil : Satuan Jenis: Si Fulan, Udara, Panas, Bumi

Tandus: Satu-Satunya

5

Eksistensi Manusia, Pencipta Kedua: Alam Kreatif

Spirinualitas

Nafs

6

Alam Budaya Besar: Kumpulan Jenis Kebudayaan : Ilmu,

Kesenian, Teknologi

7

Alam Budaya Kecil: Matematika, Wayang Kulit, Komputer: Satu-Satunya

Pertama, eksistensi diri Tuhan sendiri yang menjadi awal dan akhir segala yang ada. Kedua alam semesta sebagai wujud eksistensinya yang metafisik, gaib tak terbatas. Ketiga, alam besar yanng mempunyai kumpulan sejenis, yang abstrak, yang dapat ditangkap melalui konsep, sifatnya terbatas dan dapat dilihat, terutama pada tujuan jenis seperti manusia, bumi, langit, air, udara, tumbuh-tumbuhan dan seterusnya. Kempat alam kecil, yang menjadi satuan-satuan terkecil dari jenis yang faktual, yang nyata secara 
fisik, seperti manusia yang bernama si fulan, adalah satu-satunya nama yang ada dijalan A. Kelima eksistensi manusia yang diberi kebebasan untuk berbuat, sehingga dikatakan sebagai pencipta kedua, setelah Tuhan. Manusia secara rasio termasuk dalam alam kreatif dan secara psikis mempunyai daya spiritual. Keenam, alam budaya, baik budaya besar, seperti ilmu, kesenian, dan teknologi maupun budaya kecil, seperti, matematika, wayang kulit, komputer dan seterusnya (Asy'ari, 2002: 194-195).

Eksistensi Tuhan yang berupa alam dengan mudah dapat dipahami manusia bahwa alam semesta adalah ciptaan Tuhan. Dalm Islam hanya ada dua pencipta. Pertama, pencipta pertama yang tidak terbatas dan pencipta relatif. Pencipta kedua adalah yang terbatas. Pencipta mutlak sebagai eksistensi nafs. Kekuatan mutlak dan pencipta relatif sebagai eksistensi nafs Tuhan. Pencipta kedua sebagai eksistensi nafs manusia sifatnya terbatas.

Dalam hirarki diatas proses penciptaan pada hakekatnya hanya terjadi pada alam (Herarki ke 3 sampai ke 7), herarki ke 3 diciptakan oleh Tuhan sendiri dan pada alam ke 4 tercipta oleh proses mekanisme hukum alam besar. Sedangkan herarki ke 6 dan ke 7 ditentukan oleh kapasitas konseptual manusia. Proses-proses penciptaan ini terlihat oleh hukum-hukum penciptaan yang mensyaratkan adanya beberapa faktor, yaitu pencipta, bahan, waktu, model, metode, proses dan tujuan (Asy'ari, 2002: 197). Adapun untuk mencari jawaban tentang persoalan penciptaan herarki ke 3 dan ke 4 yang pealing tepat adalah melalui pendekatan perenungan dan pemahaman terhadap fiman-firman Tuhan tentang penciptaan itu. Kajian ilmiah untuk mengetahuai bagaimana Tuhan menciptakan alam ke herarki ke 3 dan ke 4 adalah kurang memadahi, karena ada aspek yang berkaitan dengan eksistensi Tuhan. Sedangkan kajian ilmiah yang tepat untuk mengetahui penciptaan alam pada herarki ke 6 dan ke 7 .

Al Quran mengisyaratkan bahwa yang menciptakan segala sesuatu (Maha Pencipta) adalah Allah (al Quran: 32: 4). Allah yang menciptakan langit dan bumi serta apa yang ada diantara keduanya dalam enam hari, kemudian Dia berkuasa atas Arsy. Tiada pelindung dan penolong bagi kamu selain Dia, maka apakah kamu tidak mengambil pelajaran? Sedangkan 
waktu yang dipakai untuk mencipta alam semesta selama 6 hari, bahan yang dipakai Tuhan untuk menciptakan langit dimungkinkan dari asap. Penjelasan Tuhan: Kemudian Dia menuju langit dan langit itu berupa asap, lalu Dia berkata kepada langit dan bumi: datanglah kamu berdua dengan patuh atau terpaksa. Keduanya (langit dan bumi) berkata : kami datang dengan patuh (QS. Fushshilat: 11). Kemudian bahan penciptaan manusia berasal dari tanah. Tuhan menjelaskan: Dia mulai menciptakan manusia dari tanah, kemudian Dia-menjadikan keturunan manusia dari air mani yang hina, kemudian Dia menyempurnakannya dan meniupkan kepadanya dari RuhNya, dan Dia menjadikan untuk kamu pendengaran, penglihatan, dan hati, sedikit sekali kamu bersyukur (QS. as Sajdah: 7-9).

Konsep harmoni yang blebih jelas dapat dijabarkan melalui mekanisme alam. Mekanisme alam adalah suatu sistem hukum yang mengatur kehidupan yang ada dalam herarki ke 3 dan ke 4 yang telah ditetapkan Tuhan sejak awal penciptaannya dan dapat bekerja secara otomatis. Hal ini dimaksudkan untuk mengontrol kehidupannya dalam batas-batâs yang sudah ditentukan, baik batas waktu, batas ruang, batas fungsi dan batas cara kembalinya kepada Tuhan. Tuhan sendiri menjelaskan: Sesungguhnya Tuhan kamu ialah Allah yang telah menciptakan langit dan bumi dalan 6 hari. Kemudia Dia berada di Arsymengatur segala urusan. Tidak seorangpun sebagai pemberi Syafa'at kecuali dengan izinNya. Itulah Allah Tuhan kamu, maka sembahlah Dia. Maka apakah kamu tidak mengambil pelajara? (QS. Yunus: 3-4).

Alam semesta yang menganut hukum keteraturan, di jelaskan Tuhan dalam firmanNya : Sesungguhnya pada penciptaan langit dan bimu, pertukaran malam dan siang, kapal yang berlayar dilautan yang memberi manfaat kepada manusia, air hujan yang diturunkan Tuhan dari langit, maka dihidupkannya bumi yang sudah mati dan berkeliaranlah berbagai bangsa binatang dan perkisaran angin-angin yang disuruh bekerja diantara langit dan bumi. Sesungguhnya semua itu menjadi bukti kebenaran untuk orang-orang yang beriman (QS. al Baqarah: 164).

Di ruang angkasa terdapat bintang-bintang yang terbit dan tenggelam, menurut waktu, tempat dan ukurannya masing-masing, matahari, bulan yang

Ulul Albab, Vol. 10, No. 1, 2009 
terbit dan tenggelam, bergerak tanpa henti, perbedaan wilayah Timur dan Barat yang mempunyai karakter yang berbeda, bumi dan segala isinya yang selalu bergerak mengelilingi matahari. Semua itu berjalan melalui tempattempat yang sudah diterbitkan, dengan perhitungan tertentu pula, tidak akan berlebih atau berkurang.

Putaran bumi mengelilingi matahari yang disebut ada waktu sore dan ada waktu pagi, waktu terbit dan waktu tenggelam. Manusia bisa memperkirakan kehidupannya dengan ukuran waktu, seperti siang dan malam. Waktu tidak pernah berhenti dan tidak pernah melakukan kesalahan, hukum keteraturan yang dinamakan harmoni telah diciptakan oleh Tuhan melalui mekanisme alam. Perubahan waktu terus berlanjut, tetapi semuanya mengandung unsur harmoni. Siang waktu yang tepat untuk bekerja dan malam waktu yang tepat untuk istirahat. Bekerja membutuhkan sinar terang dan tenaga kuat, istirahat membutuhkan waktu santai dan nyaman.

Leibniz mengakui atas kebebasan manusia. Wilayah kebebasan manusia menurut Islam dibatasi pada alam hirarki 6 dan 7 sebagai tiruan dan turunan alam herarki 3 dan 4. Dalam batas wilayah ini konsep Islam adalah manusia sebagai kholifah, yaitu kedudukan untuk meneruskan tugas penciptaan yang hanya memungkinkan diberikan kepada Manusia, bukan kepada makhluk lain, karena manusia mempunyai kemampuan konseptual. Tuhan menjelaskan: Hai sekalian jin dan manusia jika kamu mampu menembus penjuru langit dan bumi maka tembuslah. Kamu tidak akan bisa menembus kecuali dengan kekuasaan (QS. Arrahman: 33).iLeibniz menegaskan Tuhan yang menciptakan alam, tetapi tidak mengatur terus menerus. Mekanisme alam atau harmoni telah diciptakan Tuhan secara kosmos sejak awal penciptaannya. Untuk menjaga harmoni ini, manusia perlu diberi kekuasaan yang disebut kemampuan konseptual.

Ada tiga kemampuan konseptual manusia untuk hidup di alam harmoni ini, pertama, konsep tentang ruang, kedua konsep tentang waktu dan ketiga konsep tentang gerak.

Ruang adalah suatu dimensi yang bersifat keluasan (eksistensi) yang dapat dibedakan antara ruang yang tidak terbatas dan ruang yang 
terbatas. Ruang yang tidak terbatas adalah ruang Tuhan. Dalam ruang Tuhan ini terdapat segal sesuatu yang diciptakan Tuhan, baik yang ghoib maupun yang nyata. Ruang Tuhan tidak dapat diukur. Ruang terbatas adalah batas-batas atau ukuran benda yang berada diluarnya, bukan didalam bendanya, kemudian membentuk batas-batas ruang dimana benda-benda itu bertempat di dalamnya (Asy'ari, 2002: 204).

Ruang tak terbatas ada karena adanya ruang yang terbatas. Ruang terbatas selalu memerlukan ruang yang memungnkinkan ruang terbatas itu ada. Oleh karena itu ruang tak terbatas harus ada sebagai tempat kembalinya dari semua yanga ada. Jika ruang tak terbatas tidak ada, kemana kembalinya ruang yang terbatas. Tuhan memperkenalkan dirinya sebagai ruang tak terbata : Kami akan memperlihatkan kepada mereka tanda-tanda kami pada segenap penjuru dan pada diri mereka sendiri, sehingga jelaslah bagi mereka bahwa sesungguhnya itu adalah kebenaran. Tidaklah cukup bahwa sesungguhnya Dia menyaksikan segala sesuatu? (QS. Fushshilat: 53).

Demikian pula tentang waktu, ada wktu yang tidak terbatas dan waktu yang terbatas.Adanya waktu yang terbatas, mengharuskan adanya waktu yang tidak terbatas. Dalam Islam perhitungan waktu mèlalui pergantian siang dan malam yang diwujudkan dalam perhitungan detik, menit, jam, hari, bulan dan tahun, tetapi waktu bagi individualitas bersifat subyektif. Dialah yang menjadikan matahari bersinar dan bulan bercahaya dan Dia tentukan perjalanannya supaya kamu mengetahui bilangan tahun dan perhitungannya. Allah menjadikannya semua itu dengan benar. Dia menerangkan tandatandaNya bagi kaum yang mengetahui (QS. Yunus: 5).

Gerak adalah ukuran kehidupan. Gerak meliputi seluruh perubahan bentuk kualitas, kuantitas, posisi maupun potensi. Secara material gerak terkait dengan perubahan lokasi dari benda-benda yang relatif satu sama lainatau gerak yang diberikan dari luar pada suatu benda. Gerak tidak saja berhubungan dengan perubahan materi, melainkan meliputi hubungan perubahan imateri dan spiritual (Asy'ari, 2002: 157).

Sifat gerak kehidupan adalah mencair dan mengalir. Mencair dalam arti selalu mencari bentuk-bentuk sintetik, sedangkan mengalir adalah 
pergerakan kehidupan yang menuju keasal usulnya. al Quran menjelaskan tentang sumber kehidupan adalah air.

Dan apakah orang-orang yang ingkar itu tidak mengetahui bahwa sesungguhnya langit dan bumi adalah kéduanya terpadu, lalu kami pisahkan keduanya dan kami jadikan segala sesuatu yang hidup dari air, apakah mereka tidak percaya? (QS. al Anbiyaa': 30).

Pada hakekatnya gerak hidup adalah penghidupan. Gerakan yang tidak menghidupkan bertentangan dengan hakekat kehidupan itu sendiri. Bumi yang hidup adalah bumi yang dapat menghidupkan tumbuhan, yang menjadi dasar bagi kelangsungan kehidupan yang lainnya, binatang dan juga manusia.

\section{Simpulan}

Latar belakang Leibniz sebagai seorang ahli filsafat yang mendasarkan pada logika dan metafisika, memperkuat dan bahkan memerinci konsep Islam tentang harmoni. Konsep Pre-established Harmony Leibniz memerinci konsep al Quran yang masih global. al Quran menjelaskan harmoni melalui konsep eksistensi Tuhan, penciptaan alam dan keteraturan kehidupan manusia di dunia, tetapi tidak menjelaskan tentang struktur monade yang membentuk ketertiban kehidupan, dengan gambaran kinerja jumlah jamyang tak terhingga. Scott Gordon membuka jalan bagi pemahaman konsep harmoni Leibniz dari sudut pandang al Quran dengan gambaran mekanisme orkestra.

Selama ini keteraturan kehidupan lebih dipahami dari konsep al Quran secara tekstual dari sudut pandang teologis. Leibniz telah membuka pemahaman umat Islam tentang tertib dan keselarasan dari sudut pandang filsafat dan metafisika.

Keselarasan antara pandangan Libniz dengan, al Quran adalah terletak pada eksistensi Tuhan yang di kejawantahkan dalam.alam semesta. Leibniz berpendapat bahwa Tuhan adalah super monade. Menurut al Quran Tuhan adalah al Khaliq, sedangkan selain Tuhan disebut al Makhluq, sedangkan Leibniz menyebutnya monade.

Ulul Albab, Vol. 10, No. 1, 2009 
Menempatkan pemikiran Leibniz dalam pandangan Islam adalah sesuatu yang relevan. Dalam Islam ada tiga aliran, pertama aliran Qodariyah, yang menyatakan bahwa Tuhan menciptakan dunia dan tidak ikut campur dalam pengaturannya. Dunia tidak deterministik. Kedua aliran Jabariyah yang berpendapat bahwa Tuhan menciptakan dunia dan ikut mengaturnya secara langsung. Manusia hanya menjalani ketetapan menurut catatan lembaran Tuhan.Dunia menjadi deterministik. Ketiga aliran Asyari'ah yang berpendapat bahwa Tuhan menciptakan dunia dan pengaturannya diserahkan kepada manusia dan Tuhan sebagai pengontrol. Posisi Leibniz dalam aliran Islam mengikuti aliran Asyari'ah.

Ulul Albab, Vol. 10, No. 1, 2009 


\section{Daftar Pustaka}

Ahnan, Maftuh. Tt. Filsafat Manusia. Yogyakarta: Bintang Pelajar.

Al Quran al-Karim. Terjemahan oleh Depag, RI, 2000.

Asy'ari, Musa. 2002. Filsafat Islam, Sunah Nabi Dalam Berpikir. Yogyakarta: LESFI.

Russel, Bertrand. 2002. Sejarah Filsafat Barat. Terjemahan oleh Kamdani. Yogyakarta: Pustaka Pelajar.

Solomon, Robert. C. 2000. Sejarah Filsafat. Terjemahan oleh Saut Pasaribu. Yogyakarta: Bentang Budaya. 